\title{
Phytochemical Analysis, Computational Modeling and Experimental Evaluations of Avicennia Marina Anti-cancer Activity on Breast, Ovarian and Cervical Cancer Cell Lines Running Title: Anti-cancer Activity of Avicennia Marina
}

\section{Alireza Afshar}

Bushehr University of Medical Sciences

Arezoo Khoradmehr

Bushehr University of Medical Sciences

Masoud Zare

Bushehr University of Medical Sciences

Neda Baghban

Bushehr University of Medical Sciences

Gholamhossein Mohebbi

Bushehr University of Medical Sciences

Alireza Barmak

Bushehr University of Medical Sciences

Mohsen Khatami

Bushehr University of Medical Sciences

Mehdi Mahmudpour

Bushehr University of Medical Sciences

Adel Daneshi

Bushehr University of Medical Sciences

Afshar Bargahi

Bushehr University of Medical Sciences

Hossein Azari

Bushehr University of Medical Sciences

Iraj Nabipour

Bushehr University of Medical Sciences

Mujib Ullah

Stanford University

Morteza Anvari

Shahid Sadoughi University of Medical Sciences 
Amin Tamadon ( $\square$ amintamaddon@yahoo.com )

Bushehr University of Medical Sciences

\section{Research Article}

Keywords: Avicennia marina, anti-cancer, mangrove, apoptosis, caspase, cell cycle arrest

Posted Date: September 2nd, 2021

DOI: https://doi.org/10.21203/rs.3.rs-835233/v1

License: (c) (1) This work is licensed under a Creative Commons Attribution 4.0 International License. Read Full License 


\section{Abstract}

Background: Avicennia marina, the gray mangrove, is an herbal source of bioactive anti-cancer compounds.

Purpose: The present study aimed to evaluate phytochemical compositions of ethanol and ethyl acetate extracts of $A$. marina leaves and experimental study and computational modeling of their anti-cancer activity on breast, ovarian and cervical cancer cell lines.

Study design: Phytochemical analysis, computational modeling and experimental in vitro evaluation

Methods: Phytochemical analysis and GC-MS analysis were used to detect phenolic and flavonoid contents in ethanol and ethyl acetate extracts of $A$. marina leaves. Cell proliferation, viability, cycle and western blot assays of the extracts were performed on MCF-7, OVCAR3, and HeLa. Computational modeling done to detect effective compounds.

Results: The extracts of $A$. marina leaves had high phenolic and flavonoid contents. In GC-MS analysis of the extracts, anti-cancer and anti-proliferative compounds were detected. Moreover, after treatment of MCF-7, OVCAR3, and HeLa, separately, the MTT assay, cell proliferation assay, and cell viability assays showed anti-proliferative activity, decreasing of cell population and decreasing cell viability, respectively. In addition, the cell cycle analysis showed that the S phase of the cell cycle increased in MCF-7. Moreover, the western blot analysis showed that the pro-apoptotic cell effectors such as Bax and caspase-1, -3 , and -7 increased. Computational results of affinity of ligands detected by GC-MS compounds and stimulated apoptosis effectors detected by western blot showed five molecules in A. marina leaves playing role in OVCAR3 and HeLa apoptosis.

Conclusion: The extracts of $A$. marina leaves have anti-cancer effects on breast, ovarian and cervical cancer cells via cell cycle arrest or apoptotic mechanisms.

\section{Introduction}

Breast cancer, cervical cancer, and ovarian cancer are the first, the second, and the fourth most common female-specific cancers in worldwide, respectively [1-3]. An average of $51 \%$ of various types of cancer patients uses complementary and alternative medicine [4]. The herbal medicine, as a common approach to cancer treatment, showed various species of herbs have anti-cancer, anti-metastatic, anti-proliferative, anti-oxidant and/or pro-apoptotic effects [5]. Mangrove forests are known as one of the most productive ecosystems in the world, and they grow mainly in the tropical or sub-tropical regions [6]. Mangrove plants have been known as resources of traditional and herbal medicine [7]. Mangrove includes several kinds of phytochemical compounds which are being used for various diseases treatments [8].There are rich sources of the seven most common chemical constituents in mangrove species, including terpenoids, tannins, steroids, alkaloids, flavonoids, saponins, and glycosides [9]. For instance, it was shown that the gedunin, a tetranortriterpenoid compound, extracted from mangroves displays an anti-proliferative 
activity against breast cancer and ovarian cancer [10]. Similarly, crude extracts of mangroves showed to have cytotoxic effects against the cervical cancer HeLa cells [11].

The Avicennia is one of the true mangroves from the Acanthaceae family [12]. Globally, there are eight species of Avicennia [7]. Avicennia marina has wide geographical distribution from the Indian ocean to the western parts of the Pacific Ocean [13]. The A. marina is the most common species in the mangrove forests of the Persian Gulf [14, 15]. Polyphenols, presented in flavonoids, have been linked with anticancer activities of the mangrove crude extracts [16]. Polyphenolic compounds are found in abundance in mangrove species, especially in A. marina [17]. The A. marina also has some polyphenol compounds, especially flavonoids such as flavones, catechins, flavanols, and isoflavonoids are well recognized to exhibit a potent anticancer activity $[16,18]$. These compounds have a wide range of therapeutic properties such as anti-microbial [19], cardiovascular protection [20], and especially antioxidants [21] and anti-cancer effects [22]. Evidence suggested that mangrove-derived bioactive compounds had anti-cancer effects through multiple functional mechanisms, including the modulation of cell cycle signaling [23], removal of cancerous agents [24], apoptosis [25], cell cycle arrest [26], and anti-oxidant effects [21].

In the present study, the anti-cancer effects of ethanol and ethyl acetate extracts of the A. marina leaves were evaluated. Phytochemical compositions were done to detect the available bioactive compounds in both extracts. Then, using experimental in vitro studies and computational modeling, the mechanism of anti-cancer activity of ethanol and ethyl acetate extracts of $A$. marina leaves on breast, ovarian and cervical cancer cell lines were determined.

\section{Materials And Methods}

\section{Ethical approval}

\section{statements}

This investigation was performed in accordance with relevant guidelines and regulations of the ethical committee of Shahid Sadoughi University of Medical Sciences (Permission number:

IR.SSU.RSI.REC.1397.027).

\section{A. marina collection and extractions}

The leaves of $A$. marina were collected from the Bushehr subtidal region, shores of the Persian Gulf, Iran. Authentication of collected $A$. marina was done by a specialist from the Persian Gulf Marine Biotechnology Research Center, Bushehr University of Medical Science. The leaves of A. marina were airdried in the dark at a room temperature and were powdered. The powders were subjected to ethanol and ethyl acetate extractions.

For ethanol extraction, $40 \mathrm{~g}$ of dried leaves powder was dissolved in $100 \mathrm{~mL}$ of $70 \%$ ethanol (Merck, Germany) solvent. The extraction process was continued by shaking the mixture continuously for 3 days 
at room temperature in the dark condition. Then, the ethanol was evaporated by a rotary evaporator (Laborota 4003-control, Heidolph Instruments GmbH \& CO. KG, Germany). For ethyl acetate extraction, $40 \mathrm{~g}$ of dried leaves powder was dissolved in $100 \mathrm{~mL}$ of ethyl acetate (Merck, Germany) for 3 days at room temperature and then ethyl acetate was evaporated by rotary evaporator (Laborota 4003-control, Heidolph Instruments GmbH \& CO. KG, Germany). Then, the obtained extracts were applied for phytochemical analysis, including total phenolic and total flavonoid contents. Furthermore, the cell apoptotic and anti-proliferative effects of two extracts were tested on cancer cell lines including MCF-7, OVCAR3, and HELA and normal cells, Vero cell line.

\section{Phytochemical analysis of A. marina extracts}

\section{Total phenolic content of A. marina extracts}

The total amount of polyphenol contents of the extracts was measured by Folin-Ciocalteu method [27]. The calibration curve was determined on the basis of gallic acid (Merck, Germany). In detail, $20 \mathrm{mg}$ of gallic acid was dissolved in $100 \mathrm{~mL}$ of $50 \%$ methanol $(200 \mu \mathrm{g} / \mathrm{mL})$ and then diluted to $25,50,75$, and 100 $\mu \mathrm{g} / \mathrm{mL}$. Afterward, $100 \mu \mathrm{L}$ of each concentration, $0.5 \mathrm{~mL}$ of Folin-Ciocalteu reagent (Merck, Germany), and $1 \mathrm{~mL}$ of $20 \%$ sodium carbonate (Merck, Germany) were mixed and kept in the dark for $1 \mathrm{~h}$. The total amount of polyphenols was determined by ultraviolet spectrophotometry (CECIL, England) at a wavelength of $765 \mathrm{~nm}$. A similar procedure was adopted for both ethanol and ethyl acetate extracts. All determinations were measured in triplicate. The results of both ethanol and ethyl acetate extracts were separately compared with the calibration curve.

\section{Total flavonoid content of A. marina extracts}

The total flavonoid content was measured by the aluminum chloride colorimetric method [28]. At first, different concentrations of quercetin (Fluorochem, United Kingdom) solutions including 25, 50, 75, and $100 \mu \mathrm{g} / \mathrm{mL}$ was prepared by dissolving in methanol solution and then $100 \mu \mathrm{L}$ of the standard agent (quercetin), $0.2 \mathrm{~mL}$ of the aluminum chloride (Merck, Germany) solution and $0.1 \mathrm{~mL}$ of $33 \%$ aqueous acetic acid were added in a tube and well stirred. Finally, the materials were mixed by adding $90 \%$ ethanol until the solutions' volume reached $5 \mathrm{~mL}$ and it was kept at room temperature for $30 \mathrm{~min}$. The total amount of flavonoid was determined by ultraviolet spectrophotometry (CECIL, England) at a wavelength of $415 \mathrm{~nm}$. A similar procedure was performed for both extracts. Briefly, in the previous procedure, instead of quercetin agent, the same concentrations of ethanol and ethyl acetate extracts were separately used for flavonoid content measurement. All determinations were measured in triplicate.

\section{GC-MS analysis of A. marina extracts}

The extracts were lyophilized and were subjected to the 7890B Agilent Gas Chromatography-Mass Spectroscopy (GC-MS). Electron ionization (El) mass spectra (scan range, $\mathrm{m} / \mathrm{z} 50-500$ ) were obtained using electrons with an energy of $70 \mathrm{eV}$. The filament emission was $0.5 \mathrm{~mA}$. The $\mathrm{GC}$ separations were performed using an HP-5MS UI column ( $30 \mathrm{~m} \times 0.25 \mathrm{~mm}$ i.d., film thickness $0.5 \mu \mathrm{m})$. Helium, as the 
carrier gas, was used with the flow of $0.8 \mathrm{ml} \mathrm{min}^{-1}$ for El. The GC oven was temperature programmed at $5^{\circ} \mathrm{C} \min ^{-1}$ from $80^{\circ} \mathrm{C}$ after 3 min since the sample injection and held at $250^{\circ} \mathrm{C}$ for 10 min. The injection port of the gas chromatograph, the transfer line, and the ion source of 5977MSD were maintained at $240^{\circ} \mathrm{C}, 250^{\circ} \mathrm{C}$, and $220^{\circ} \mathrm{C}$, respectively. Identification of the separated compounds was performed by comparing them with the compound data of the National Institute of Standards and Technology (NIST MS database, 2014) library. The relative percentage of each compound was measured by average peaks area in comparison with the total areas.

In vitro analysis of $A$. marina extracts

\section{Cell culture}

For in vitro study, breast cancer cell line (MCF-7), ovarian carcinoma cell line (OVCAR3), cervical cancer cell line (HeLa), and normal kidney epithelial cell line (VERO) were provided (PerciaVista Co., Iran). The cell lines were cultured in Dulbecco's Modified Eagle Medium (DMEM, Gibco, Life Technologies Co., US) supplemented with 10\% fetal bovine serum (FBS, Kiazist, Iran) and 1\% penicillin-streptomycin (Pen-Strep, Gibco, Life Technologies Co., US). After seeding the cell lines, the cells were incubated at $37^{\circ} \mathrm{C}$ and $5 \%$ $\mathrm{CO}_{2}$.

\section{MTT assay and calculation of cytotoxic concentration}

The cell lines were seeded in 96-well cell culture plates and after $24 \mathrm{~h}$, the ethanol and ethyl acetate extracts of $A$. marina leaves were separately added to all cell lines in the concentrations of $40,80,120$, and $160 \mu \mathrm{g} / \mathrm{mL}$. For the control group, the DMEM supplemented with 10\% FBS and the same concentration of dimethyl sulfoxide (DMSO, Sigma-Aldrich Co., Darmstadt, Germany) was added to the wells. The samples were incubated at $37^{\circ} \mathrm{C}$ and $5 \% \mathrm{CO}_{2}$ for $72 \mathrm{~h}$. Then, the media were removed and the cells were washed with phosphate buffer saline (PBS). For cell vitality assessment, $100 \mu \mathrm{L}$ of MTT (3(4,5-dimethylthiazol-2-yl)-2,5-diphenyltetrazolium bromide) assay kit (Sigma-Aldrich Co., Darmstadt, Germany) with the concentration of $5 \mathrm{mg} / \mathrm{mL}$ and incubated for $4 \mathrm{~h}$ until the formation of the intracellular purple formazan crystals. After that, the supernatant was removed and DMSO was added to each well and incubated at $37^{\circ} \mathrm{C}$ and $5 \% \mathrm{CO}_{2}$ for $20 \mathrm{~min}$. The absorbance of cells in each plate was read at a wavelength of $573 \mathrm{~nm}$ using an ELISA plate reader machine (BioTek, USA). This step was repeated three times. Then, $50 \%$ cell cytotoxic concentration $\left(\mathrm{CC}_{50}\right)$ of $A$. marina leaves for both extracts was calculated via nonlinear regression of "log (inhibitor) vs. normalized response” in Graph pad prism (v7.0a, GraphPad Software, Inc., San Diego, CA, USA).

\section{Growth curve assay and population doubling time}

The cell lines were seeded in 24-well cell culture plates at a density of $4 \times 10^{4}$ cells per well. Concentrations of $40,80,120$, and $160 \mu \mathrm{g} / \mathrm{mL}$ of ethanol extract and ethyl acetate extract of $A$. marina leaves were prepared in $10 \mathrm{~mL}$ DMEM supplemented with 10\% FBS and $10 \mathrm{~mL}$ of DMSO, respectively. The cells were treated separately with crude ethanol and ethyl acetate extracts for $24 \mathrm{~h}$. After that, the number of cells in 
three wells was counted every 24 hours (each time three wells/group). This procedure was repeated for 7 days, and the mean number of the cells on each day was obtained. In more detail, the culture medium supplemented with crude extracts was changed on day 3 . The following formula was used to determine population doubling time (PDT): $\mathrm{T} \times \ln 2 / \ln (\mathrm{Xe} / \mathrm{Xb})$, where $\mathrm{Xe}, \mathrm{Xb}$, and $\mathrm{T}$ were defined as the final cell number, the initial cell number, and the incubation time in any unit, respectively.

\section{Cell viability assessment}

Trypan blue exclusion method was selected for the cell viability. In detail, the cell lines were seeded at a density of $4 \times 10^{4}$ cells per well. The cells were treated with $40,80,120$, and $160 \mu \mathrm{g} / \mathrm{mL}$ concentrations of ethanol extract and ethyl acetate extract of $A$. marina leaves and were incubated at $37^{\circ} \mathrm{C}$ in the presence of $5 \% \mathrm{CO}_{2}$ for $72 \mathrm{~h}$. After that, the cells were treated with $300 \mu \mathrm{L}$ of $0.5 \%$ trypsin enzyme (Kiazist Co., Iran). Finally, $20 \mu \mathrm{L}$ of medium contained detached cells and an equal volume of trypan blue were mixed and viable, and dead cells were counted by hemocytometer chamber. The cell viability was measured by the following formula: Cell viability $(\%)=$ (number of non-stained cells/number of total cells) $\times 100$.

\section{Cell cycle and apoptosis analyses by flow cytometry}

The proportion of apoptotic cells was determined by flow cytometry. Based on the findings of cell MTT assay, cell viability test, and PDT assay, the most effective concentrations of the extracts were determined and used for cell cycle assay in each cell line. The cells in the logarithmic growth phase were taken for experimental intervention. After $72 \mathrm{~h}$ cell exposure to extracts, cells were digested, washed, and prepared as the single-cell suspension. The cell density was provided into $1-5 \times 10^{5} \mathrm{cells} / \mathrm{mL}$. Then, 500 $\mu \mathrm{L}$ of binding buffer was added to suspend cells and mixed gently. Afterward, $5 \mu \mathrm{L}$ of annexin-V-FITC and $5 \mu \mathrm{L} \mathrm{PI}$ were added to cells and they were incubated in the dark condition at room temperature for $15 \mathrm{~min}$. The procedure was followed by I h using Flow Cytometry (FACS, Becton, Dickinson, USA). The experimental results were analyzed using BD Cell Quest software (BD Biosciences Co., USA).

\section{Western blot analysis}

Western blot analysis was done based on standard procedures with slight modifications [29]. Based on the findings of cell MTT assay, cell viability test, and PDT assay, the most effective concentrations of the extracts were determined and used for western blot analysis in each cell line. In details, after $72 \mathrm{~h}$ cell exposure to extracts, cells were lysed by RIPA buffer including $50 \mathrm{mM}$ Tris $-\mathrm{HCl}(\mathrm{pH}=8.0), 0.4 \%$ Nonidet P-40, $120 \mathrm{mM} \mathrm{NaCl}, 1.5 \mathrm{mM} \mathrm{MgCl}_{2}, 2 \mathrm{mM}$ phenylmethylsulfonyl fluoride, $80 \mu \mathrm{g} / \mathrm{mL}$ leupeptin, $3 \mathrm{mM} \mathrm{NaF}$, and $1 \mathrm{mM} \mathrm{DTT}$ at $4^{\circ} \mathrm{C}$ for $20 \mathrm{~min}$. The lysates were centrifuged at $12000 \times \mathrm{g}$ for $20 \mathrm{~min}$ at $4^{\circ} \mathrm{C}$, and the protein concentration was measured by a Bradford protein assay. Proteins were then transferred to a microporous polyvinylidene difluoride membrane (Millipore, France). Membranes were incubated in $5 \%$ BSA (Sigma, USA) blocking buffer for $1 \mathrm{~h}$ at room temperature. After blocking, the membranes were incubated with the corresponding primary antibodies separately overnight at $4^{\circ} \mathrm{C}$. Immunoblotting was performed with rabbit anti-Bcl-2, anti-Bcl-xl, anti-Bax, anti-caspase-1, -3, and - 7 antibodies (1:200) (Cell Signaling Technology, Danvers, MA). Membranes were washed three times (10 min each) in tween buffer before incubating with HRP-conjugated goat anti-mouse or rabbit secondary antibodies. To remove 
excess antibodies, membranes were washed four times before HRP activities were detected using ECL Plus Chemiluminescence Reagent (Amersham, Chalfont, UK) according to the protocol supplied with the kit.

\section{Computational details}

\section{Ligand and Receptor preparation}

Thirty-three compounds derived from the Persian Gulf $A$. marina and five proteins were selected for the docking process. The three-dimensional (3D) structure of ligands and receptors was downloaded from the PubChem database and the Protein Database Bank (PDB), respectively. HyperChem software version 8.0.10 was used to optimize the geometry of compounds. Chimera 1.15 was used to prepare receptors. The receptor preparation process includes removing all non-standard residues, water, and original hydrogens, the addition of polar hydrogen, charges and bond orders, and capping $\mathrm{N}$ and $\mathrm{C}$ termini. Finally, the format of all outputs was converted to a suitable format for the docking process.

\section{Generation of grid}

The generation of the grid box is an important step in the docking process. To generate a grid box, the position of the active site of each receptor was found using available structures with a co-crystallized ligand for BAX, BCL-2, Caspase-1, Caspase-3 and Caspase-7 with PDB code of 4zie, 600K, 6f6r, 4quj and $2 q \mid 9$, respectively. Then, a grid box with a dimension of $35 \times 35 \times 35 \AA^{3}$ and a spacing of $0.375 \AA$ was generated at the active-site of each receptor using AUTOGRID.

\section{Study of target proteins-marine derived compounds interactions}

In order to study interactions of target proteins and selected compounds, the docking process was performed using Autodock Vina 1.1.2 after generating the grid box. Among different conformations suggested by software for each ligand, the best one was selected according to the binding affinity score and RMSD given by the software. In order to validate the accuracy of the docking process, the cocrystallized ligand (1,2-ethanediol, LBM, CVE, MPD, and CIT for 4zie, 600K, 6f6r, 4quj and 2ql9, respectively) were re-docked. The best conformations of the co-crystallized ligands were reasonably located at the original active-site with RMSD $\leq 2 \AA$.

\section{Statistical analysis}

IBM SPSS Statistics 26 software (SPSS for Windows, version 26, SPSS Inc, Chicago, Illinois, USA) was used for statistical analysis of data. The results were presented as mean \pm standard error of mean. The measurement results received the homogeneity test of variance. Comparison between groups was done using one-way ANOVA and post hoc LSD test (for comparing the MTT and cell proliferation and viability assays) or chi-square test (for comparing the cell cycle analysis and flow cytometry). The $p<0.05$ was 
considered as the statistically significant difference. The graphs were drawn by Graph pad prism (v7.0a, GraphPad Software, Inc., San Diego, CA, USA).

\section{Results}

Total phenolic content of the ethanol extract of A. marina leaves was higher than the ethyl acetate extract

The ethanol extract of $A$. marina had a higher yield of extractions than the ethyl acetate extract of the $A$. marina. The total phenolic content of $A$. marina extracts was determined. The calibration curve generated from the analysis of the standard (gallic acid) was linear (Figure S1A). In detail, the ethanol extract of $A$. marina showed higher phenolic content $(345 \mu \mathrm{g} / \mathrm{ml}$ gallic acid $/ 0.01 \mathrm{~g}$ extract) than ethyl acetate extract $(147.5 \mu \mathrm{g} / \mathrm{ml}$ gallic acid/0.01 g extract).

Total flavonoid content of the ethanol extract of A. marina leaves was higher than the ethyl acetate extract

The total flavonoid content of both ethanol and ethyl acetate extracts of $A$. marina was determined. The calibration curve generated from the analysis of the gallic acid was linear (Figure S1B). In addition, the equation and parameter were $y=0.0009 x+0.0155$ and $R 2=0.9081$, respectively. The results showed that the ethanol extract of $A$. marina had a higher flavonoid content ( $47.8 \mathrm{mM} \mathrm{GAE})$ than ethyl acetate extract (38.6 mM GAE).

GC-MS profile of the ethanol and ethyl acetate extracts of A. marina leaves showed anti-cancer compounds

GC-MS analyses revealed several different molecules in the ethanol and ethyl acetate extracts of $A$. marina leaves (Figure S2). Sixty compounds were identified in the ethanol extract of $A$. marina leaves (Table S1). In detail, there were 26 compounds with anti-cancer and apoptotic effects based on the previous researches. In addition, 56 compounds were detected in the ethyl acetate extract of $A$. marina leaves (Table S2). Twenty of these compounds had anti-cancer and apoptotic effects based on the previous studies. The effects of both ethanol and ethyl acetate compounds on three cell lines (MCF-7, OVCAR3, and HeLa) were also evaluated in Tables S1 and S2. Moreover, other biological activities were observed in A. marina extracts including anti-oxidant, anti-inflammatory, antimicrobial, and anti-fungal activities are summarized in Tables S1 and S2.

\section{MTT proliferation test of ethanol extracts of A. marina leaves had anti-proliferative effects on MCF-7}

The anti-proliferative effect of 120 and $160 \mu \mathrm{g} / \mathrm{mL}$ concentrations of ethanol extract was observed on the MCF-7 cell line $(p<0.05$, Fig. 1A). However, the extract had a proliferative effect on OVCAR3 cell lines at 40,80 , and $120 \mu \mathrm{g} / \mathrm{mL}$ concentrations ( $p<0.05$, Fig. 1B). In contrast, the ethanol extract of $A$. marina had no significant effects on the HeLa cell line at different concentrations (Fig. 1C). In addition, the ethanol extract of $A$. marina had also an anti-proliferative effect on the Vero cell line at the concentrations of 40 
and $160 \mu \mathrm{g} / \mathrm{mL}(p<0.05$, Fig. 1D). Therefore, ethanol extract of $A$. marina leaves at $120 \mu \mathrm{g} / \mathrm{mL}$ had antiproliferative effects on MCF-7 cancer cell lines comparing with normal Vero cells.

Moreover, the ethyl acetate extract had no significant effects on MCF-7 and OVCAR3 cell lines (Figs. 1E and $1 F$ ). The anti-proliferative effect of ethyl acetate extract was observed at the concentration of 160 $\mu \mathrm{g} / \mathrm{mL}$ on the HeLa cell line ( $p=0.01$, Fig. $1 \mathrm{G})$. The ethyl acetate extract had also anti-proliferative effects on the Vero cell line at the concentration of 120 and $160 \mu \mathrm{g} / \mathrm{mL}(p<0.05$, Fig. $1 \mathrm{H})$. Therefore, ethyl acetate extract of $A$. marina leaves had no applied anti-proliferative effects on three cancer cell lines comparing with normal Vero cells.

\section{A. marina leaves had cytotoxic activity on MCF-7 by ethanol extract and HeLa by ethyl acetate extract}

The ethanol and ethyl acetate extracts of $A$. marina leaves potentially inhibited the viability of MCF-7 cells, OVCAR3 cells, HeLa cells, and Vero cells with $\mathrm{CC}_{50}$ values of 70 and $102 \mu \mathrm{g} / \mathrm{mL}, 1087$ and 272 $\mu \mathrm{g} / \mathrm{mL}, 189$ and $67 \mu \mathrm{g} / \mathrm{mL}$, and 382 and $242 \mu \mathrm{g} / \mathrm{mL}$, respectively. As shown in Figs. $2 A$ and 2B, these two extracts had significant dose-dependent inhibition on the proliferation and viability of the MCF-7 and HeLa cancer cells. The results showed that the cytotoxic activity of these extracts on MCF-7 and HeLa cancer cells was more active than OVCAR3 cancer cells and Vero normal cells.

\section{Cancer cell count decreased by ethanol and ethyl acetate extract treatments}

The ethanol extract decreased MCF-7 cell number at 7 days ( $p<0.05$, Figure S3A). Increasing the concentrations of ethanol extract 1.5 times increased the PDT of MCF-7 cells (Table 1). In addition, the ethanol extract decreased OVCAR3 cell number at five days ( $p<0.05$, Figure S3B). A dose-dependent increase of PDT to two to five times was seen on the effect of ethanol extract on OVCAR3 cell proliferation (Table 1). The ethanol extract decreased HeLa cell number from day 6 ( $p<0.05$, Figure S3C). Increasing the concentrations of ethanol extract 1.8 times increased PDT of HeLa cells (Table 1). The ethanol extract decreased Vero cell number at days $7(p<0.05$, Figure S3D). A dose-dependent increase of PDT to 1.5 times was seen on the effect of ethanol extract on the Vero cell proliferation (Table 1). 
Table 1

Mean of population doubling time of MCF-7, OVCAR3, HeLa and Vero cell lines after exposure to different concentrations $(\mu \mathrm{g} / \mathrm{mL})$ of ethanol and ethyl acetate extracts of Avicennia marina leaves

\begin{tabular}{|llllll|}
\hline Extracts & Concentrations $(\mu \mathrm{g} / \mathrm{mL})$ & \multicolumn{4}{c|}{ Population doubling time (PDT) (days) } \\
\cline { 3 - 6 } & & MCF-7 & OVCAR3 & HeLa & Vero \\
\hline Ethanol & 0 & 1.1 & 2.5 & 1.5 & 1.1 \\
& 40 & 1.3 & 6 & 1.7 & 1.6 \\
& 80 & 1.3 & 4.2 & 2 & 1.6 \\
\hline & 120 & 1.4 & 10.6 & 2 & 1.6 \\
\hline Ethyl acetate & 0 & 1.6 & 5 & 2.8 & 1.6 \\
\hline & 160 & 1.1 & 2.5 & 1.4 & 1.1 \\
\hline & 40 & 1.5 & 3.4 & 1.5 & 1.3 \\
\hline 120 & 1.6 & 2.8 & 1.6 & 1.5 \\
\hline 160 & 1.4 & 2.7 & 2.9 & 1.4 \\
\hline
\end{tabular}

Moreover, the ethyl acetate extract decreased MCF-7 cell number at 5 days $(p<0.05$, Figure S3E). Increasing the concentrations of ethyl acetate extract 1.8 times increased PDT of MCF-7 cells (Table 1). In addition, the ethyl acetate extract decreased OVCAR3 cell number at five days ( $p<0.05$, Figure S3F). A dose-dependent increase of PDT to 2.7 times was seen on the effect of ethyl acetate extract on the OVCAR3 cell proliferation (Table 1). The ethyl acetate extract decreased HeLa cell number from days 7 ( $p$ $<0.05$, Figure S3G). Increasing the concentrations of ethyl acetate extract 2 times increased PDT of HeLa cells (Table 1). The ethyl acetate extract decreased Vero cell number at 3 days $(p<0.05$, Figure $\mathrm{S} 3 \mathrm{H})$. A dose-dependent increase of PDT to 1.5 times was seen on the effect of ethyl acetate extract on the Vero cell proliferation (Table 1).

\section{A. marina ethanol extracts reduced the viability of OVCAR3 and HeLa cells}

$160 \mu \mathrm{g} / \mathrm{mL}$ ethanol extract of $A$. marina leaves decreased OVCAR3 and HeLa cells viability from day 2 ( $p$ $<0.05$, Figs. 3B and 3C). The $160 \mu \mathrm{g} / \mathrm{mL}$ ethyl acetate extract of $A$. marina leaves decreased the viability of OVCAR3, HeLa and Vero cells from days 6,5 , and 5 , respectively $(p<0.05$, Figs. $3 F$ and $3 G)$.

\section{Cell cycle analysis of HeLa cell lines showed an increase of dead cells}

Based on the findings of the cell MTT assay, PDT assay, and cell viability test, the most effective concentrations of the extracts were determined and used for cell cycle assay (Fig. 4). The MCF-7 cell line was treated with $120 \mu \mathrm{g} / \mathrm{mL}$ concentration of ethanol extract of $A$. marina leaves that 2-times increased 
the number of cells in the S phase. The OVCAR3 cell line was treated with $160 \mu \mathrm{g} / \mathrm{mL}$ concentration of ethyl acetate extract. The HeLa cell line was treated with $120 \mu \mathrm{g} / \mathrm{mL}$ concentration of ethyl acetate extract. The proportion of dead cells increased in HeLa cells after treatment with ethyl acetate extract of A. marina leaves $(p<0.05$, Fig. $4 \mathrm{I})$.

Cell apoptosis analysis of MCF-7, OVCAR3, and HeLa cell lines showed increase of apoptotic cells by A. marina leaves extracts

Based on the findings of the cell MTT assay, PDT assay, and cell viability test, the most effective concentrations of the extracts were determined and used for cell apoptosis assay (Fig. 5). The MCF-7 cell line was treated with $120 \mu \mathrm{g} / \mathrm{mL}$ concentration of ethanol extract of $A$. marina leaves. The OVCAR3 and HeLa cell lines were treated with $160 \mu \mathrm{g} / \mathrm{mL}$ and $120 \mu \mathrm{g} / \mathrm{mL}$ of ethyl acetate extract, respectively. After treating the HeLa, MCF-7, and OVCAR3 cell lines, the proportion of apoptotic cells increased $(p<0.05$, Figs. 5G-5I).

\section{Western blot analysis showed an increase of BAX, caspase-1, -3, and - 7 expressions in MCF-7, OVCAR3, and HeLa cell lines by A. marina leaves extracts}

The MCF-7 cell line was treated with $120 \mu \mathrm{g} / \mathrm{mL}$ concentration of ethanol extract of $A$. marina leaves. The OVCAR3 and HeLa cell lines were treated with $160 \mu \mathrm{g} / \mathrm{mL}$ and $120 \mu \mathrm{g} / \mathrm{mL}$ of ethyl acetate extract, respectively. Expressions of BAX, cleaved-caspase-1, -3 , and -7 increased in MCF-7, OVCAR3, and HeLa, and cell lines after treatment (Fig. 6). However, expressions of BCL-2, pro-caspase-1, -3 , and -7 decreased in MCF-7, OVCAR3, and HeLa cell lines after treatment (Fig. 6).

Five bioactive molecules in A. marina leaves extracts had the highest affinity to apoptotic peptides

Thirty-three compounds derived from ethanol and ethyl acetate extracts of the A. marina leaves (Table 2) have been selected based on the previous studies as anti-cancer compounds (Tables S1 and S2) to study their binding affinity to apoptotic proteins $B A X, B C L-2$, caspase- $1,-3$, and -7 through the docking process. Though, the ligand-protein complexation is controlled by conformations and intermolecular interactions such as electrostatic and Van der Waals forces [30]. The most stable complex has the lower negative energy or binding affinity, $\Delta \mathrm{G}$ [U total in $\mathrm{kcal} / \mathrm{mol}]$, as the lower negative energy indicates the more favorable ligand-protein interaction. The results of the docking process are shown in Table 2. According to Table 2, the binding affinity is in the range of -3.6 to $-10.8 \mathrm{kcal} / \mathrm{mol}$. Among selected compounds, ergosta-5,22-dien-3-ol, acetate shows the best affinity for caspase-7. Stigmasterol shows the best affinity for BAX. Beta amyrin shows the best binding affinity for BCL-2, caspase- 1 and caspase-7. Moreover, it was found that three compounds of alpha amyrin, beta amyrin and cholesta-22, 24-dien-5-ol,4,4-dimethyl have the same affinity to caspase-3. The intermolecular interactions of these compounds are shown in Fig. 7. 
Table 2

The results of the docking process of anti-cancer compounds in ethanol and ethyl acetate extracts of Avicennia marina leaves and their interactions with apoptotic peptides in cancer cells

\begin{tabular}{|c|c|c|c|c|c|}
\hline \multirow[t]{2}{*}{ Ligands } & \multicolumn{5}{|c|}{ Binding affinity (Kcal/mol) } \\
\hline & BAX & $\begin{array}{l}\text { BCL- } \\
2\end{array}$ & $\begin{array}{l}\text { Caspase } \\
1\end{array}$ & $\begin{array}{l}\text { Caspase } \\
3\end{array}$ & $\begin{array}{l}\text { Caspase } \\
7\end{array}$ \\
\hline (R)-3-hydroxydecanoic acid & -4.8 & -4.8 & -4.9 & -4.3 & -5.6 \\
\hline 2,4-Di-Tert-Butylphenol & -6.4 & -6 & -5.7 & -4.8 & -7.3 \\
\hline 2-Tridecanol & -4.8 & -5 & -4.5 & -4.1 & -5.6 \\
\hline 4-Butoxy-2-methyl-2-pentanyl acetate & -4.6 & -5.2 & -4.7 & -4.5 & -6.1 \\
\hline 9,12-Octadecadienoyl chloride & -5.6 & -5.8 & -4.2 & -3.9 & -6.4 \\
\hline Alpha amyrin & -8.4 & -8.4 & -7.3 & -6.7 & -8.3 \\
\hline Beta amyrin & -7.7 & -9.5 & -7.6 & -6.7 & -6.6 \\
\hline Betulin & -7.8 & -7.4 & -6.5 & -6.2 & -8.1 \\
\hline Cholesta-22, 24-dien-5-ol,4,4-dimethyl & -8.4 & -8.2 & -6.9 & -6.7 & -10.5 \\
\hline Cyclohexanol 1-methyl-4-(1-methylethyl)- & -5.3 & -6 & -5.4 & -4.7 & -5.8 \\
\hline Decanoic acid & -4.7 & -4.8 & -4.5 & -3.9 & -5.3 \\
\hline Dihydrocarveol & -5.3 & -5.8 & -5.2 & -4.3 & -6.1 \\
\hline Dodecane & -4.5 & -4.6 & -4.3 & -4.2 & -5.2 \\
\hline Ergosta-5,22-dien-3-ol, acetate & -8.7 & -8.1 & -6.8 & -6.2 & -10.8 \\
\hline Ethyl oleate & -5 & -5.7 & -4.4 & -4.5 & -6.7 \\
\hline Gamma-Sitosterol & -5 & -8.5 & -6.2 & -6 & -10.1 \\
\hline Hexadecane & -4.8 & -4.7 & -3.6 & -3.7 & -6.1 \\
\hline $\begin{array}{l}\text { Hexadecanoic Acid 2-Hydroxy-1-(Hydroxymethyl) } \\
\text { Ethyl Ester }\end{array}$ & -5.6 & -5.4 & -4.7 & -4.1 & -6.2 \\
\hline Levoglucosan & -5.3 & -4.8 & -4.2 & -4.2 & -4.9 \\
\hline Linoleic acid & -5.6 & -5.6 & -4.8 & -4.2 & -6.7 \\
\hline Lupeol & -8.3 & -7.9 & -6.8 & -6.5 & -8.4 \\
\hline Myristic acid & -5.1 & -5 & -4.8 & -4 & -6.1 \\
\hline Myristoleic acid & -5.2 & -5.4 & -4.8 & -3.9 & -6.4 \\
\hline Norspermidine & -3.3 & -3.6 & -4 & -3.4 & -4.1 \\
\hline
\end{tabular}




\begin{tabular}{|lccccc|}
\hline Ligands & \multicolumn{7}{c|}{ Binding affinity (Kcal/mol) } \\
\cline { 2 - 7 } & BAX & BCL- & Caspase & Caspase & Caspase \\
\hline Octadecanoic acid & & $\mathbf{2}$ & $\mathbf{1}$ & $\mathbf{3}$ & $\mathbf{7}$ \\
\hline Octadecanoic acid, ethyl ester & -5.1 & -5 & -4.6 & -4 & -6.3 \\
\hline Palmitic acid & -5.2 & -5.1 & -4.4 & -4.1 & -6.1 \\
\hline Pentadecanoic acid & -5.1 & -5 & -4.9 & -4 & -6.1 \\
\hline Phenylmethyl ester & -5.1 & -5.3 & -4.1 & -3.6 & -6.2 \\
\hline Phytol & -6 & -5.4 & -4.5 & -4 & -7.7 \\
\hline Squalene & -5.9 & -5.8 & -4.5 & -4.5 & -6.9 \\
\hline Stigmasterol & -7.3 & -7.8 & -4.7 & -4.4 & -9.5 \\
\hline Vitamin E & -8.8 & -8.4 & -6.6 & -6 & -10 \\
\hline
\end{tabular}

\section{Discussion}

Ethanol and ethyl acetate extracts of A. marina leaves have anti-cancer compounds

Thirty-three compounds of both ethanol and ethyl acetate extracts of $A$. marina had anti-cancer biological effects. Previous studies showed that the linoleic acid compound had anti-cancer activity on MCF-7, OVCAR3 and HeLa cell lines [31-33]. Other anti-cancer compounds of A. marina extracts have shown in Tables S1 and S2. These results suggest the potent anti-cancer and cytotoxic effects of ethanol and ethyl acetate extracts of $A$. marina on cancer lines. The results of the current study demonstrated that both ethanol and ethyl acetate extracts of $A$. marina had polyphenol and flavonoid contents. Consistent with our results, it has been shown that one of the phytochemical compounds of $A$. Marina is polyphenols such as flavonoids [34]. In detail, the ethanol extract had a higher phenolic and flavonoid content than ethyl acetate extract. Previous study also showed the same result in which the ethanol extract of Sonneratia apetala, another species of mangrove, had higher polyphenol content [35]. The previous study has shown that the polyphenol content and especially flavonoid content of foods are related to decreasing risk factors of some diseases such as cancer [36]. Polyphenols can inhibit cell growth and induce apoptosis through downregulation of surviving gene expression, a member of the inhibitor apoptosis protein family (IAP) that inhibits caspases and blocks cell death and Bcl-2 [37]. Polyphenols upregulate BAX expression in cancer cell lines leading to a pro-apoptotic situation which was accompanied by the upregulation of p21 and p27 leading to cell death due to activation of caspase-3 and - 9 [37]. It was shown that the A. marina, a mangrove species, has anti-cancer and anti-proliferative activities on different cell lines [38]. Therefore, using experimental and computational modeling of anticancer activity, we showed mechanisms of these compounds on cancer cell apoptosis or cell cycle arrests. 
Ethanol extract of A. marina leaves induced cell cycle arrest in MCF-7 breast cancer cell lines

The MTT proliferation assay and cell count analysis showed that ethanol extract of $A$. marina leaves decreased proliferation of MCF-7 $\left(\mathrm{ER}^{+}, \mathrm{PR}^{+}\right)$breast cancer cell line. Consistent with our findings, the ethyl acetate extract of $A$. marina leaves reduced proliferation of AU565 (ER- $\left.\mathrm{PR}^{-}\right)$and BT483 (ER $\left.{ }^{+}, \mathrm{PR}^{+}\right)$ breast cancer cell lines [34]. Cell cycle analysis of MCF-7 with ethanol extracts showed an increase in cell population in S-phase. However, the cell viability of MCF-7 did not alter by extracts of $A$. marina leaves. In the cell cycle, there are four main phases; $\mathrm{G}_{1}$-phase in which the cell prepared for chromosome replication. At this stage, the chromosomes are $2 \mathrm{n}$. At the next stage, cells go to S-phase in which the chromosomes replicated and became $4 n$. After that, the cells undergo $G_{2}$ and mitosis $(M)$ phases in which they are prepared for cell division. The $G_{0}$-phase is another part of the cell cycle. At the $G_{0}$-phase, the cell cycle will arrest and the cell division and chromosome replication will stop [39]. In contrast with our findings, AU565 and BT483 cells were treated with ethyl acetate extract of $A$. marina leaves showed an increase in percentages of cells in the sub- $G_{1}$ phase [34]. Previous studies showed that the mangrove extract decreased cell proliferation at different concentrations [34,38,39]. Previous studies on the anticancer effects of mangrove extracts could be different due to the type of the cells, type of the extract, and different concentrations of the extract [38,40]. By the way, the current study showed that the ethanol extract of $A$. marina leaves induced its anti-proliferative effects by cell cycle arrest in MCF-7 breast cancer cell lines.

\section{Ethyl acetate extract of A. marina leaves induced apoptosis in HeLa cervical cancer and OVCAR3 ovarian cancer cell}

Cell viability of HeLa and OVCAR3 decreased by ethanol and ethyl acetate extracts of A. marina leaves. Furthermore, ethyl acetate extracts of $A$. marina leaves increased apoptosis of HeLa and OVCAR3. One of the essential parts of the cell cycle is apoptosis, which controls cell proliferation. It stops abnormal cells that contained irreversible damaged DNA [41]. In line with current results, previous studies on A. marina have shown that the different concentrations of $A$. marina extracts could induce apoptosis and increase cell population at late- and early-apoptosis, and necrosis quadrant increase [38, 42]. In the current study, Bax, cleaved caspase- 1 , cleaved caspase -3 , and cleaved caspase- 7 as pro-apoptosis effectors were increased after cell treatment and the Bcl-2, caspase-1, caspase-3, and caspase-7 as anti-apoptotic effectors decreased. B-cell lymphoma 2 protein (Bcl-2) family has a main role in the intrinsic apoptosis pathway. The Bcl-2 proteins include two subgroups: pro-apoptosis and anti-apoptosis groups. The proapoptosis group contained proteins such as Bax, Bcl-Xs, Bak, Bad, etc $[39,43]$. On the other hand, the antiapoptosis proteins contained Bcl-2, Bcl-W, Bcl-XL, cleaved caspase-7, etc. [39, 43, 44]. In normal cells, there are some balances between the pro-apoptosis (Bax) group and the anti-apoptosis ( $\mathrm{BCl}-2)$ group. However, in cancer cells, the Bcl-2 level increases and disturbs the balance. This disturbance causes inhibition of apoptosis [39, 43]. Previous studies have shown that the most important genes involved in apoptosis are Bcl-2, caspase-3, and p53 [45]. In addition, a previous study showed that inhibition of caspase-1 could induce cell death and modulate Bcl-2 expression [46]. These results demonstrated that 
treatment of the HeLa and OVCAR3 cell lines via A. marina ethyl acetate extract induced pro-apoptotic pathways and suppressed anti-apoptotic pathways (Fig. 8). It was shown that the A. marina extract triggered cell apoptosis using p53 and Bcl-2 genes that caused DNA fragmentation and cell death [42].

According to the result of the computational study, among all ligands investigated through molecular docking, five ligands (ergosta-5,22-dien-3-ol, acetate, stigmasterol, alpha amyrin, beta amyrin, and cholesta-22, 24-dien-5-ol,4,4-dimethyl) showed the highest affinity to target receptors. As illustrated in Fig. 7, several intermolecular interactions including van der Waals interactions, hydrophobic interactions, and hydrogen bonds are involved in controlling the binding of ligands to receptors. Among all of these ligands, beta amyrin, which is a triterpenoid, showed the best affinity to three receptors of BCL-2, caspase1 , and caspase-3. However, its affinity for binding to BCL-2 is more than other targets. Accordingly, beta amyrin can be introduced as one of the most effective anti-cancer contents of the $A$. marina extract. This result is in accordance with those, which have been reported on the inhibitory properties of triterpenoids against the growth and proliferation of different cancer cells such as breast and prostate cancer cells [47-49]. In addition, as the smallest value of the HOMO/LUMO energy gap shows the high biological activity of molecules [50], the $\beta \mathrm{HOMO} / \beta \mathrm{LUMO}$ gap energy $(-1.057 \mathrm{eV})$ reported for beta amyrin demonstrate good biological activity of this substance [51].

\section{Conclusions}

Ethanol and ethyl acetate extracts of $A$. marina showed to have anti-cancer biological activity on MCF-7, HeLa, and OVCAR3 cell lines. The ethanol extract induced its effects by cell cycle arrest in MCF-7. Furthermore, in HeLa and OVCAR3 cell lines, A. marina ethyl acetate extract triggered pro-apoptosis effectors of cancer cells and decreased expression of anti-apoptosis effectors; that's how it induces apoptosis in these cancer cell lines.

\section{Abbreviations}

3D, three-dimensional

\section{A. marina, Avicennia marina}

$\mathrm{CC}_{50}, 50 \%$ cell cytotoxic concentration

DMEM, Dulbecco's Modified Eagle Medium

DMSO, dimethyl sulfoxide

El, Electron ionization

FBS, fetal bovine serum

GC-MS, Gas Chromatography-Mass Spectroscopy 
HeLa, cervical cancer cell line

MCF-7, breast cancer cell line

MTT ,3-(4,5-dimethylthiazol-2-yl)-2,5-diphenyltetrazolium bromide

OVCAR3, ovarian carcinoma cell line

PDT, population doubling time

Pen-Strep, penicillin-streptomycin

VERO, normal kidney epithelial cell line

\section{Declarations}

\section{Ethics and Consent to Participate}

This investigation was performed in accordance with relevant guidelines and regulations of the ethical committee of Shahid Sadoughi University of Medical Sciences (Permission number:

IR.SSU.RSI.REC.1397.027).

\section{Consent to Publish}

Not applicable.

\section{Availability of Data and Materials}

The datasets used and/or analyzed during the current study are available from the corresponding author on reasonable request.

\section{Competing interests}

We wish to confirm that there are no known conflicts of interest associated with this publication and there has been no significant financial support for this work that could have influenced its outcome.

\section{Funding}

This work was supported by a grant from Shahid Sadoughi University of Medical Sciences. 


\section{Authors' contributions}

A. T., M. A., N. B., M. M., M. U., and I. N. conceived and designed the format of the manuscript. A. A., A. K., A. T., N. B., M. Z., G. M., A. B. 1., M. K., H. A., A. D., and A. B. 2. collected the data, and drafted and edited the manuscript. A. T., N. B, A. A., and A. K. computational and statistical analysis. N. B., A. T., A. K., and A. A. drew the Figures and Tables. All the authors reviewed the manuscript and all of them contributed to the critical reading and discussion of the manuscript. All authors have read and agreed to the published version of the manuscript.

\section{Acknowledgments}

Not applicable.

\section{References}

1. Arbyn M, Weiderpass E, Bruni L, de Sanjosé S, Saraiya M, Ferlay J, et al. Estimates of incidence and mortality of cervical cancer in 2018: a worldwide analysis. The Lancet Global Health. 2020;8(2):e191e203.

2. Zhang Y, Luo G, Li M, Guo P, Xiao Y, Ji H, et al. Global patterns and trends in ovarian cancer incidence: age, period and birth cohort analysis. BMC Cancer. 2019;19(1):984; doi: 10.1186/s12885-019-6139-6.

3. Heer E, Harper A, Escandor N, Sung H, McCormack V, Fidler-Benaoudia MM. Global burden and trends in premenopausal and postmenopausal breast cancer: a population-based study. The Lancet Global Health. 2020;8(8):e1027-e37.

4. Keene MR, Heslop IM, Sabesan SS, Glass BD. Complementary and alternative medicine use in cancer: A systematic review. Complement Ther Clin Pract. 2019;35:33-47; doi:

10.1016/j.ctcp.2019.01.004.

5. Luo H, Vong CT, Chen H, Gao Y, Lyu P, Qiu L, et al. Naturally occurring anti-cancer compounds: shining from Chinese herbal medicine. Chin Med. 2019;14(1):48; doi: 10.1186/s13020-019-0270-9.

6. Kathiresan K, Bingham BL. Biology of mangroves and mangrove ecosystems. Advances in Marine Biology. 2001;40:84-254.

7. Thatoi H, Samantaray D, Das SK. The genus Avicennia, a pioneer group of dominant mangrove plant species with potential medicinal values: a review. Frontiers in Life Science. 2016;9(4):267-91.

8. Nabeelah Bibi S, Fawzi MM, Gokhan Z, Rajesh J, Nadeem N, Kannan RRR, et al. Ethnopharmacology, phytochemistry, and global distribution of mangroves-a comprehensive review. Mar Drugs. 2019;17(4):231; doi: 10.3390/md17040231.

9. Saranraj P, Sujitha D. Mangrove medicinal plants: A review. American-Eurasian Journal of Toxicological Sciences. 2015;7(3):146-56. 
10. Sahai R, Bhattacharjee A, Shukla VN, Yadav P, Hasanain M, Sarkar J, et al. Gedunin isolated from the mangrove plant Xylocarpus granatum exerts its anti-proliferative activity in ovarian cancer cells through G2/M-phase arrest and oxidative stress-mediated intrinsic apoptosis. Apoptosis. 2020;25(78):481-99.

11. Sohimi NKA, Mohamad H, Zafar MN, Ahmed A, Sung YY, Muhammad TST. Induction of apoptosis by selected Xylocarpus sp., fractions in the human cervical cancer cell line, HeLa. International Journal of Research in Pharmaceutical Sciences. 2020;11(2):2332-9.

12. da Silva Pontes AL, Mesquita VC, de Oliveira Chaves F, da Silva AJR, Kaplan MAC, Fingolo CE. Phthalates in Avicennia schaueriana, a mangrove species, in the State Biological Reserve, Guaratiba, RJ, Brazil. Environmental Advances. 2020;2:100015.

13. Duke N. A systematic revision of the mangrove genus Avicennia (Avicenniaceae) in Australasia. Australian Systematic Botany. 1991;4(2):299-324.

14. Namazi R, Zabihollahi R, Behbahani M, Rezaei A. Inhibitory activity of Avicennia marina, a medicinal plant in Persian folk medicine, against HIV and HSV. Iranian Journal of Pharmaceutical Research. 2013;12(2):435-43.

15. Salimi L, Sezavar S, Agah H. Assessment of Cd, Ca, Zn, Cr, Al concentrations in water, sediment and tissues of mangrove forest, Avicennia marina from Qeshm Island, Persian Gulf. Indian Journal of Geo-Marine Sciences. 2019;48:899-906.

16. Dahibhate NL, Saddhe AA, Kumar K. Mangrove plants as a source of bioactive compounds: A review. The Natural Products Journal. 2019;9(2):86-97.

17. Wang Y, Zhu H, Tam NFY. Polyphenols, tannins and antioxidant activities of eight true mangrove plant species in South China. Plant Soil. 2014;374(1-2):549-63.

18. Dawane V, Pathak B. Assessment of secondary metabolite profile and quantification method development for Lupeol and Caffeic acid by HPTLC in Avicennia marina pneumatophore roots. Biocatalysis and Agricultural Biotechnology. 2020:101573.

19. Haq M, Sani W, Hossain A, Taha RM, Monneruzzaman K. Total phenolic contents, antioxidant and antimicrobial activities of Bruguiera gymnorrhiza. Journal of Medicinal Plants Research. 2011;5(17):4112-8.

20. Tangney CC, Rasmussen HE. Polyphenols, inflammation, and cardiovascular disease. Current Atherosclerosis Reports. 2013;15(5):324; doi: 10.1007/s11883-013-0324-x.

21. Dahibhate NL, Roy U, Kumar K. Phytochemical screening, antimicrobial and antioxidant activities of selected mangrove species. Curr Bioact Compd. 2020;16(2):152-63.

22. Khajehzadeh S, Behbahani M. Activity of Avicennia marina methanol extracts on proliferation of lymphocytes and their mutagenicity using ames test and in silico method. Journal of Mazandaran University of Medical Sciences. 2016;26(135):32-42.

23. Khan $H$, Reale $M$, Ullah $H$, Sureda A, Tejada S, Wang Y, et al. Anti-cancer effects of polyphenols via targeting p53 signaling pathway: updates and future directions. Biotechnol Adv. 2020;38:107385; doi: 10.1016/j.biotechadv.2019.04.007. 
24. Hazafa A, Rehman KU, Jahan N, Jabeen Z. The Role of polyphenol (flavonoids) compounds in the treatment of cancer cells. Nutrition and Cancer. 2020;72(3):386-97; doi:

10.1080/01635581.2019.1637006.

25. Sharma A, Kaur M, Katnoria JK, Nagpal AK. Polyphenols in food: cancer prevention and apoptosis induction. Curr Med Chem. 2018;25(36):4740-57; doi: 10.2174/0929867324666171006144208.

26. Wu H, Chen L, Zhu F, Han X, Sun L, Chen K. The cytotoxicity effect of resveratrol: cell cycle arrest and induced apoptosis of breast cancer 4T1 cells. Toxins (Basel). 2019;11(12); doi: 10.3390/toxins 11120731.

27. WABAIDUR SM, OBBED MS, ALOTHMAN ZA, ALFARIS NA, BADJAH-HADJ-AHMED AY, SIDDIQUI MR, et al. Total phenolic acids and flavonoid contents determination in Yemeni honey of various floral sources: Folin-Ciocalteu and spectrophotometric approach. Food Science and Technology. 2020; (AHEAD).

28. Hassan S, Al Aqil A, Attimarad M. Determination of crude saponin and total flavonoids content in guar meal. Advancement in Medicinal Plant Research. 2013;1(2):24-8.

29. Zhang J-y, Tao L-y, Liang Y-j, Chen L-m, Mi Y-j, Zheng L-s, et al. Anthracenedione derivatives as anticancer agents isolated from secondary metabolites of the mangrove endophytic fungi. Mar Drugs. 2010;8(4):1469-81.

30. Pagadala NS, Syed K, Tuszynski J. Software for molecular docking: a review. Biophys Rev. 2017;9(2):91-102; doi: 10.1007/s12551-016-0247-1.

31. Jóźwiak M, Filipowska A, Fiorino F, Struga M. Anticancer activities of fatty acids and their heterocyclic derivatives. European Journal of Pharmacology. 2020;871:172937.

32. Sagar PS, Das UN, Koratkar R, Ramesh G, Padma M, Kumar GS. Cytotoxic action of cis-unsaturated fatty acids on human cervical carcinoma (HeLa) cells: relationship to free radicals and lipid peroxidation and its modulation by calmodulin antagonists. Cancer Lett. 1992;63(3):189-98; doi: 10.1016/0304-3835(92)90260-3.

33. Ghahramanloo KH, Latiff LA, Hanachi P, Lajis NH. Inhabitation Effect of Linoleic Acid, the Ingredient of Nigella sativa (Black Seed) on MDA-MB-231 and MCF-7 Human Breast Cancer Cells. Journal of Family and Reproductive Health. 2010:179-85.

34. Huang C, Lu CK, Tu MC, Chang JH, Chen YJ, Tu YH, et al. Polyphenol-rich Avicennia marina leaf extracts induce apoptosis in human breast and liver cancer cells and in a nude mouse xenograft model. Oncotarget. 2016;7(24):35874-93; doi: 10.18632/oncotarget.8624.

35. Van Tan D, Thuy MN. Antioxidant, antibacterial and alpha amylase inhibitory activity of different fractions of Sonneratia apetala bark extract. Academia Journal of Biology. 2014;37(1 se):54-60.

36. Williamson G, Carughi A. Polyphenol content and health benefits of raisins. Nutr Res. 2010;30(8):511-9; doi: 10.1016/j.nutres.2010.07.005.

37. D’Alessandro N, Poma P, Montalto G. Multifactorial nature of hepatocellular carcinoma drug resistance: could plant polyphenols be helpful? World Journal of Gastroenterology: WJG. 2007;13(14):2037. 
38. Illian DN, Basyuni M, Wati R, Hasibuan PAZ. Polyisoprenoids from Avicennia marina and Avicennia lanata inhibit WiDr cells proliferation. Pharmacogn Mag. 2018;14(58):513.

39. Sari DP, Basyuni M, Hasibuan PA, Sumardi S, Nuryawan A, Wati R. Cytotoxic and antiproliferative activity of polyisoprenoids in seventeen mangroves species against WiDr colon cancer cells. Asian Pac J Cancer Prev. 2018;19(12):3393-400; doi: 10.31557/APJCP.2018.19.12.3393.

40. Albinhassan TH, Saleh KA, Barhoumi Z, Alshehri MA, Al-Ghazzawi AM. Anticancer, anti-proliferative activity of Avicennia marina plant extracts. J Cancer Res Ther. 2021; doi: 10.4103/jcrt.JCRT_659_19.

41. Xue X, Yu JL, Sun DQ, Kong F, Qu XJ, Zou W, et al. Curcumin induces apoptosis in SGC-7901 gastric adenocarcinoma cells via regulation of mitochondrial signaling pathways. Asian Pac J Cancer Prev. 2014;15(9):3987-92; doi: 10.7314/apjcp.2014.15.9.3987.

42. Momtazi-Borojeni AA, Behbahani M, Sadeghi-Aliabadi H. Antiproliferative activity and apoptosis induction of crude extract and fractions of avicennia marina. Iranian Journal of Basic Medical Sciences. 2013;16(11):1203-8.

43. Wong RS. Apoptosis in cancer: from pathogenesis to treatment. J Exp Clin Cancer Res. 2011;30(1):87; doi: 10.1186/1756-9966-30-87.

44. Phung HM, Lee H, Lee S, Jang D, Kim C-E, Kang KS, et al. Analysis and anticancer effects of active compounds from Spatholobi caulis in human breast cancer cells. Processes. 2020;8(9):1193.

45. Suh SS, Yang EJ, Lee SG, Youn UJ, Han SJ, Kim IC, et al. Bioactivities of ethanol extract from the Antarctic freshwater microalga, Chloromonas sp. Int J Med Sci. 2017;14(6):560-9; doi: 10.7150/ijms.18702.

46. Schlosser S, Gansauge F, Ramadani M, Beger HG, Gansauge S. Inhibition of caspase-1 induces cell death in pancreatic carcinoma cells and potentially modulates expression levels of bcl-2 family proteins. FEBS Lett. 2001;491(1-2):104-8; doi: 10.1016/s0014-5793(01)02144-5.

47. Wen S, Gu D, Zeng H. Antitumor effects of beta-amyrin in Hep-G2 liver carcinoma cells are mediated via apoptosis induction, cell cycle disruption and activation of JNK and P38 signalling pathways. J BUON. 2018;23(4):965-70.

48. Yan SL, Huang CY, Wu ST, Yin MC. Oleanolic acid and ursolic acid induce apoptosis in four human liver cancer cell lines. Toxicology in Vitro. 2010;24(3):842-8; doi: 10.1016/j.tiv.2009.12.008.

49. Bishayee A, Ahmed S, Brankov N, Perloff M. Triterpenoids as potential agents for the chemoprevention and therapy of breast cancer. Frontiers in Bioscience. 2011;16:980.

50. Perepichka DF, Bryce MR. Molecules with exceptionally small HOMO-LUMO gaps. Angew Chem Int Ed. 2005;44(34):5370-3; doi: 10.1002/anie.200500413.

51. Kamaraj M, Olikkavi K, Vennila L, Bose S, Raj SM. In silico docking studies on the anti-cancer activity of isolated compounds, (alpha and beta amyrin) from methanolic bark extract of Shorea robusta. International Journal of Pure Medical Research. 2019;4(12):11-5.

\section{Figures}


Vero

EtOH
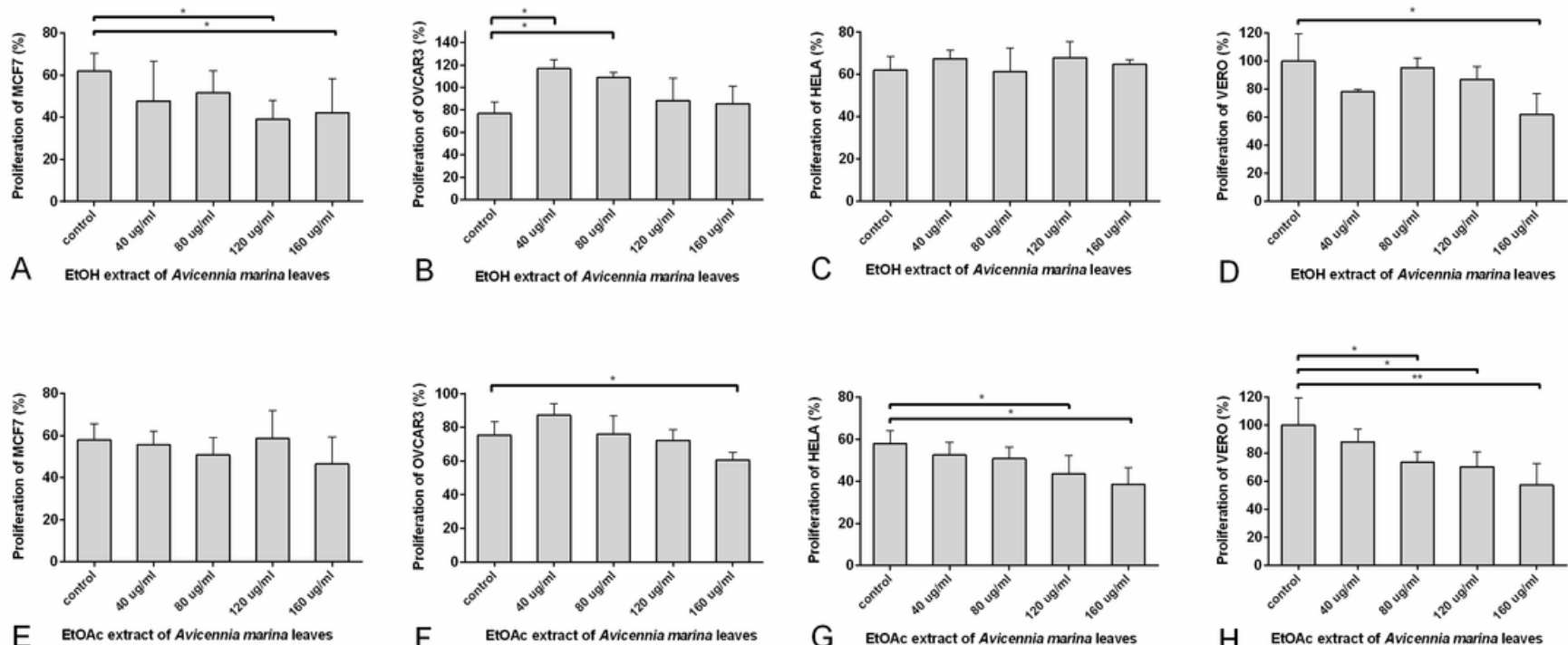

Figure 1

MTT proliferation assay of different concentrations of ethanol and ethyl acetate extracts of Avicennia marina leaves on MCF-7, OVCAR3, HeLa and Vero cell lines. Lines above the columns showed differences between treatments and control $\left({ }^{*} p<0.05\right.$ and $\left.{ }^{* *} p<0.01\right)$.

\section{Ethanol extract}

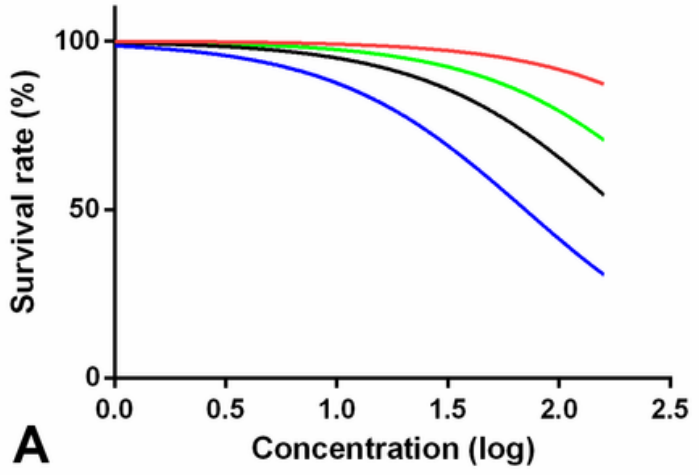

Ethyl acetate extract

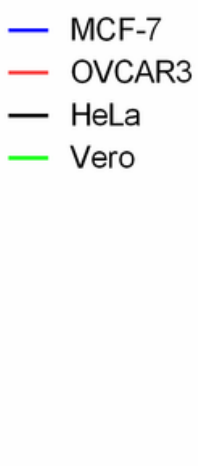

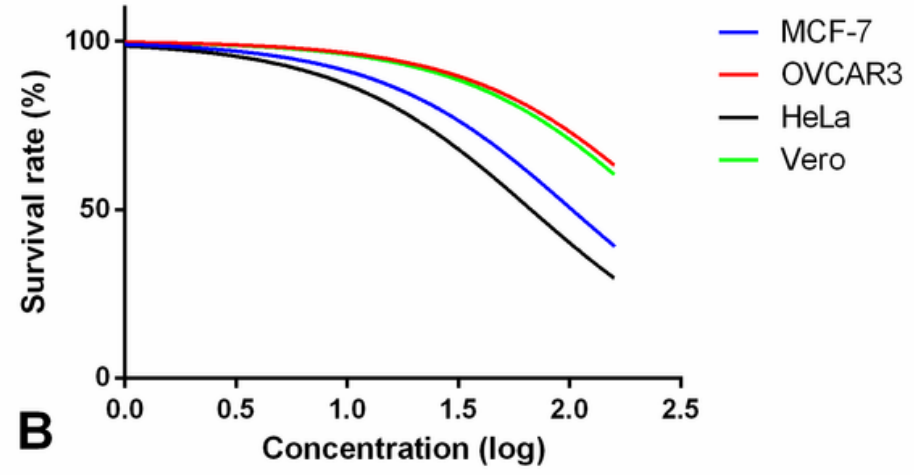

Figure 2

Cytotoxic activity of $A$ ) ethanol and B) ethyl acetate extracts from Avicennia marina against MCF-7, OVCAR3, HeLa and Vero cell lines. 
MCF7

EtOH

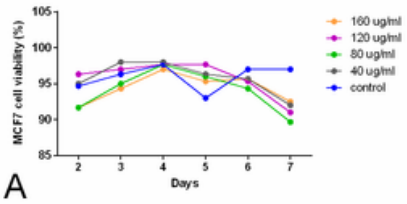

EtOAc

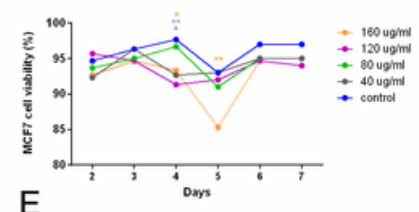

OVCAR3
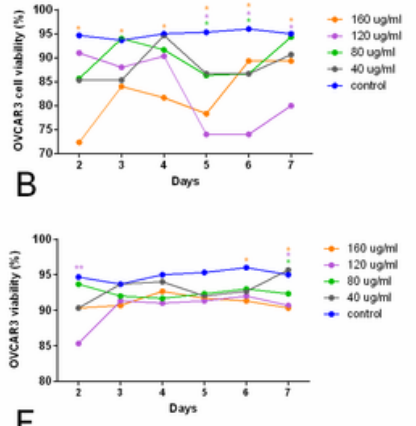

Hela

Vero
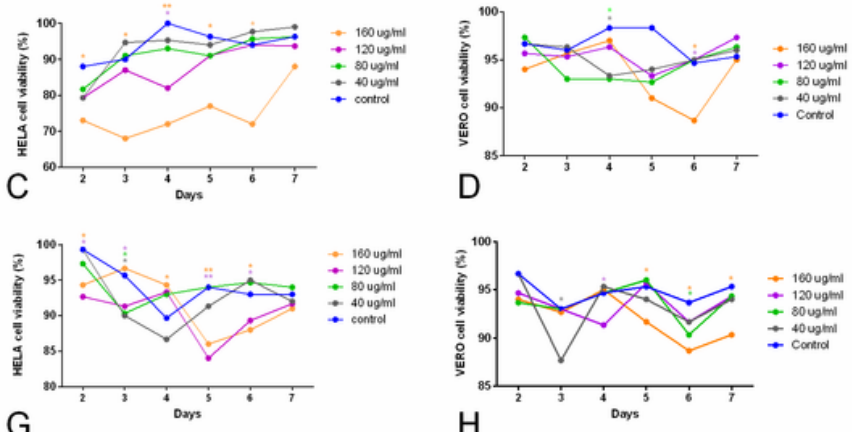

Figure 3

Cell viability assay of different concentrations of ethanol and ethyl acetate extracts of Avicennia marina leaves on MCF-7, OVCAR3, HeLa and Vero cell lines during seven days. Stars above the dots showed differences between treatments and control $\left({ }^{*} \mathrm{p}<0.05\right.$ and $\left.{ }^{* *} \mathrm{p}<0.01\right)$.
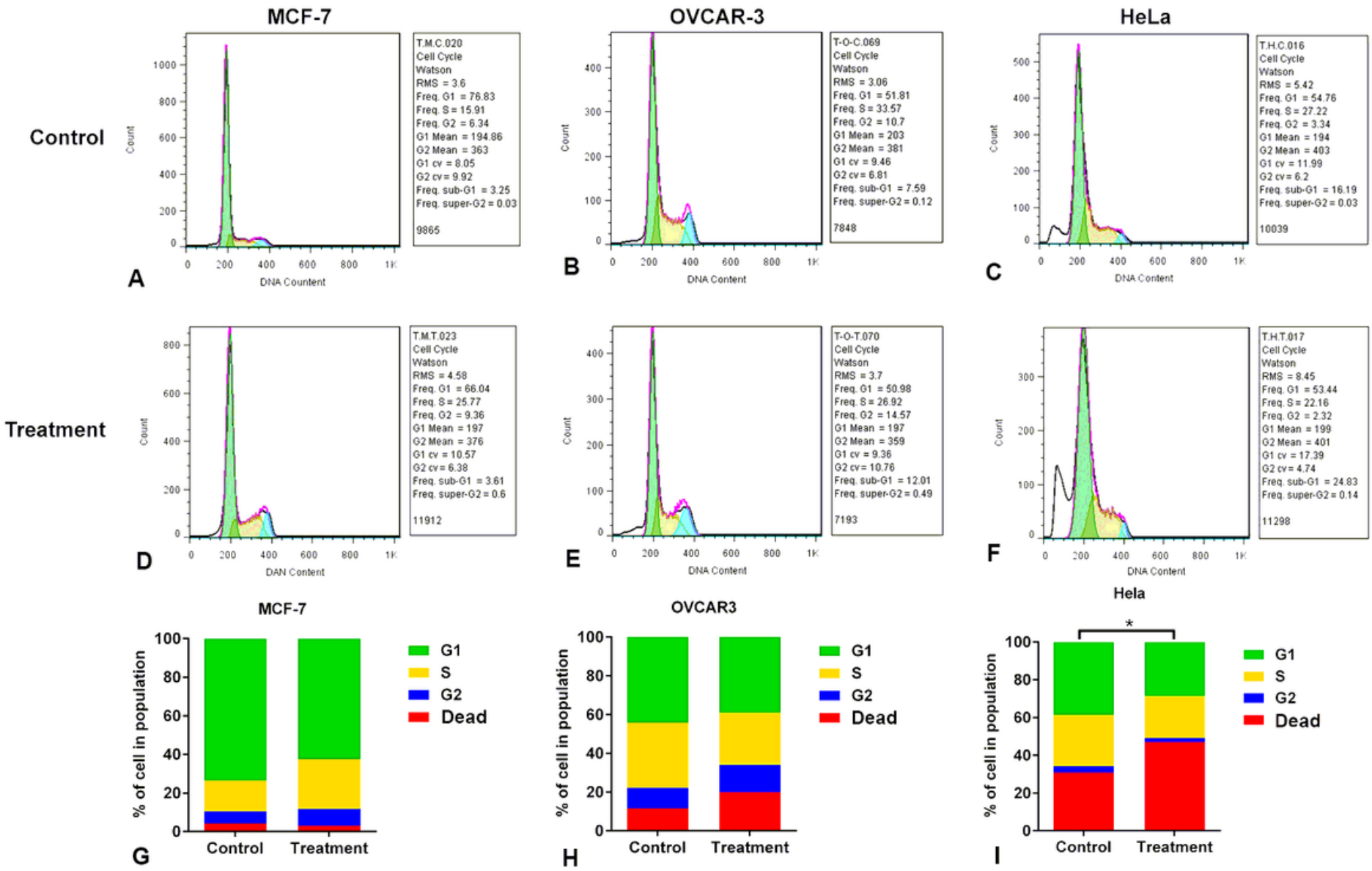

Figure 4

Cell cycle assay of extracts of Avicennia marina leaves. A) MCF-7 cell line with no treatment, B) OVCAR3 cell line with no treatment, and C) HeLa cell line with no treatment. D) MCF-7 cell line treated with 120 $\mu \mathrm{g} / \mathrm{mL}$ concentration of ethanol extract, E) OVCAR3 cell line treated with $160 \mu \mathrm{g} / \mathrm{mL}$ concentration of 
ethyl acetate extract, and F) HeLa cell line treated with $120 \mu \mathrm{g} / \mathrm{mL}$ concentration of ethyl acetate extract. $\mathrm{G}, \mathrm{H}$, and I) Comparisons of percent of cell stages in populations between control and treatment. The line above the columns shows significant differences between groups $(P<0.05)$.

HeLa
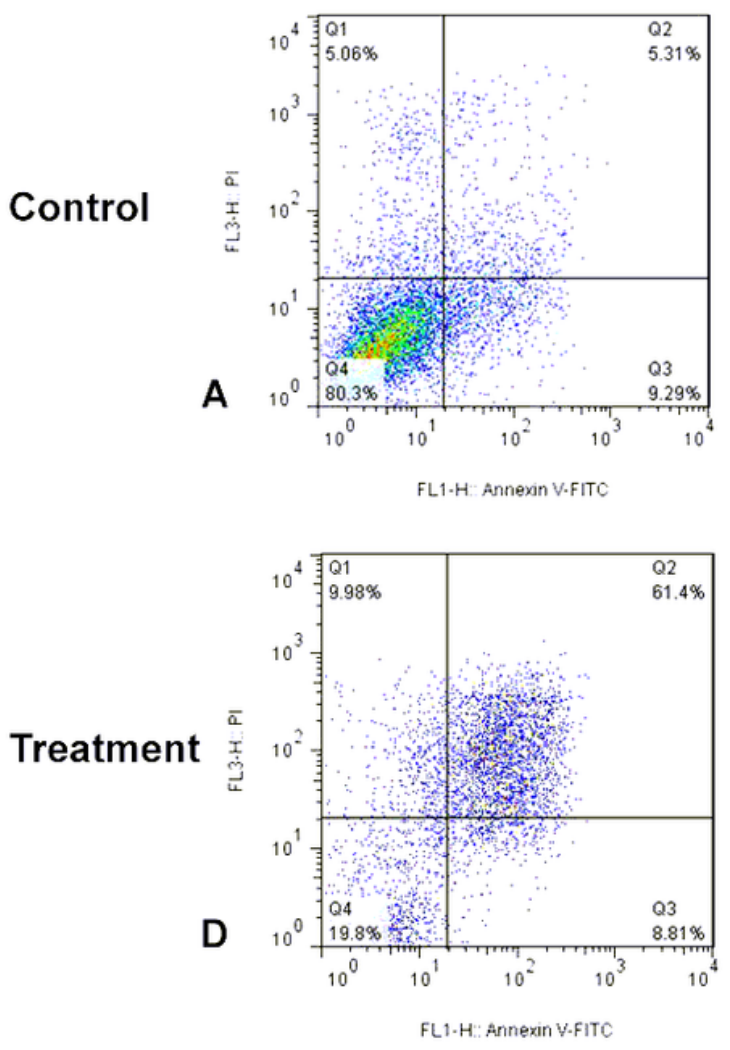

FL1.H: Annexin V.FITC

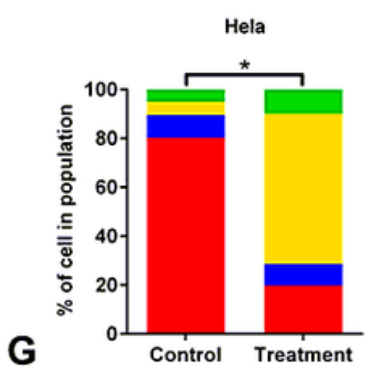

MCF-7
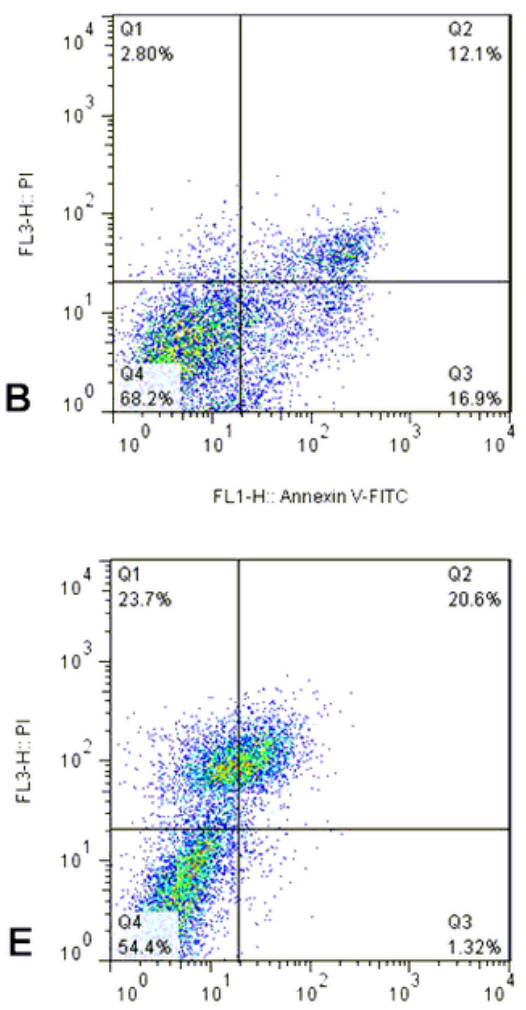

FL1.H Annexin V.FITC

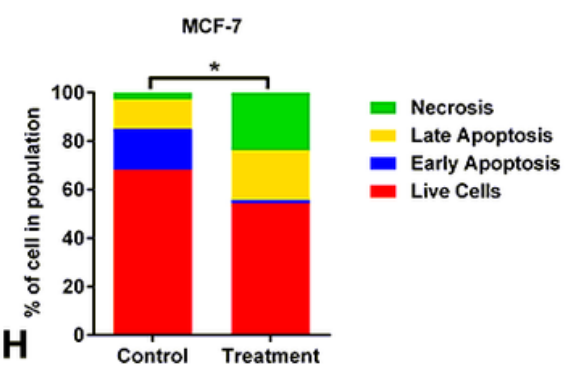

OVCAR-3
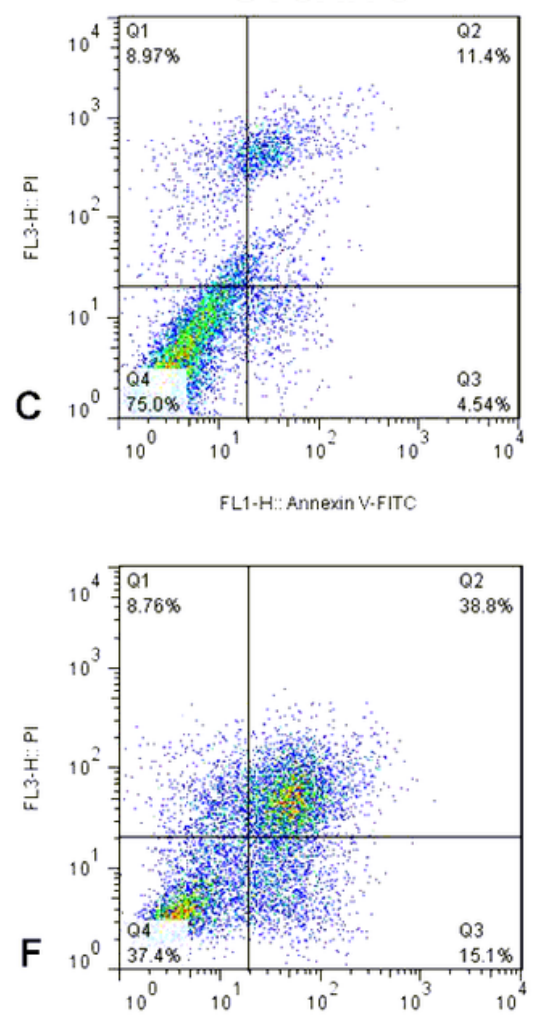

FL1-H: Annexin V-FITC

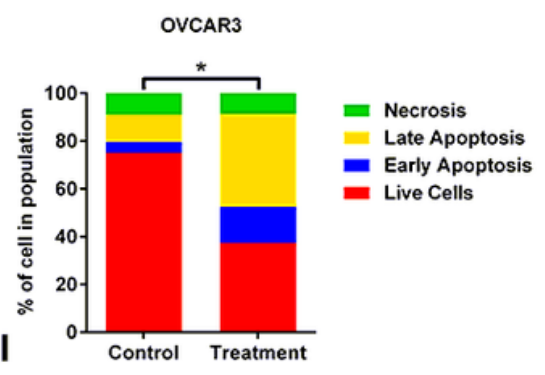

\section{Figure 5}

Cell apoptosis flow cytometry assay of HeLa, MCF-7, OVCAR3 cell lines after exposure to extracts of Avicennia marina leaves. A) HeLa, B) MCF-7, and C) OVCAR3 cell lines with no treatment as the control group. D) HeLa cell line treated with $120 \mu \mathrm{g} / \mathrm{mL}$ concentration of ethyl acetate extract. E) MCF-7 cell line treated with $120 \mu \mathrm{g} / \mathrm{mL}$ concentration of ethanol extract. F) OVCAR3 cell line treated with $160 \mu \mathrm{g} / \mathrm{mL}$ concentration of ethyl acetate extract. $\mathrm{G}, \mathrm{H}$, and I) Comparisons of percent of cell apoptosis in populations between control and treatment. The line above the columns shows significant differences between groups $(P<0.05)$. 

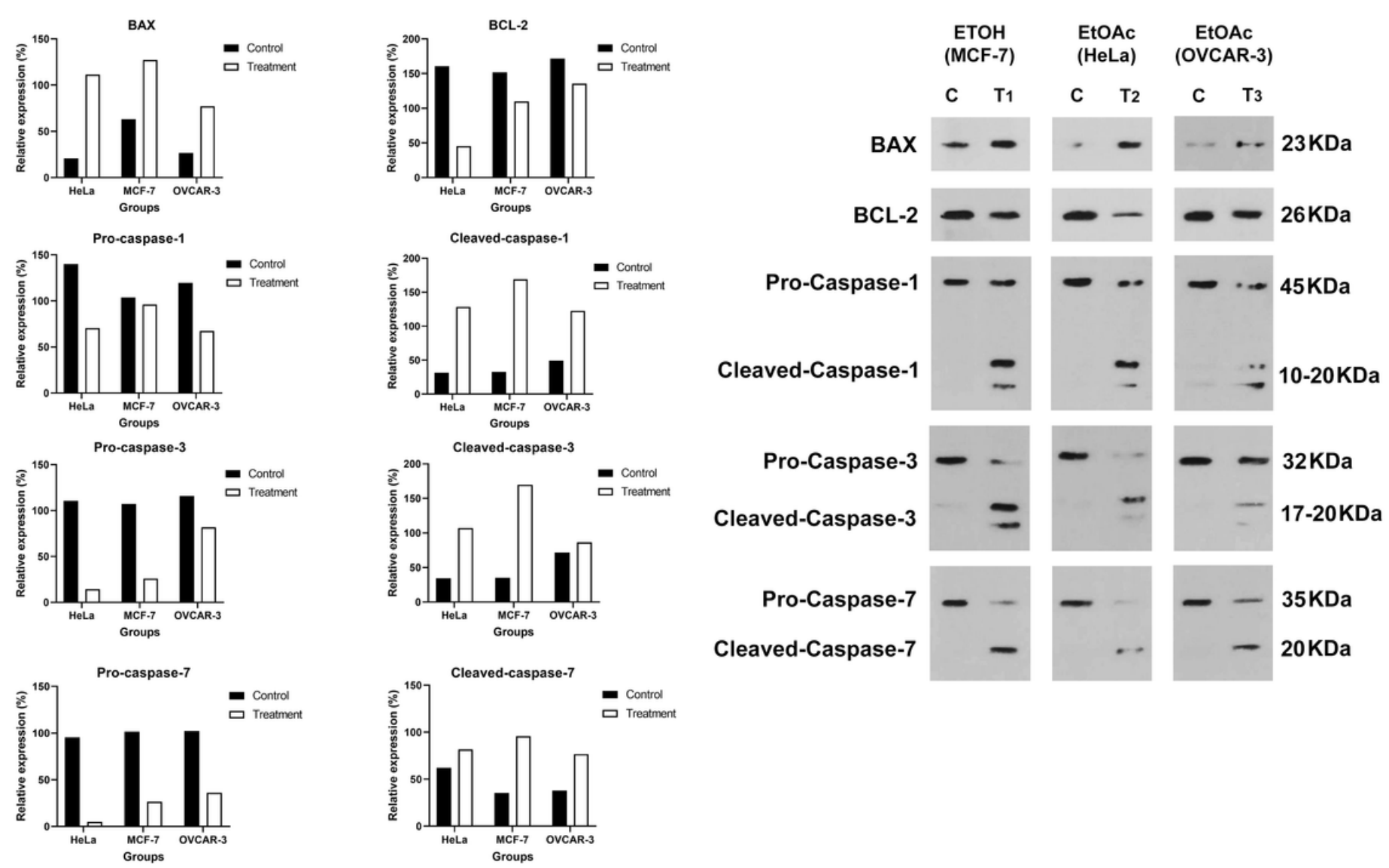

Figure 6

Expression of apoptosis proteins after treating of HeLa, MCF-7 and OVCAR3 cell lines with ethanol and ethyl acetate extracts of Avicennia marina leaves. The protein bonds of the MCF-7 cell line treated with $120 \mu \mathrm{g} / \mathrm{mL}$ concentration of ethanol extract (ETOH) extract, HeLa cell line treated with $120 \mu \mathrm{g} / \mathrm{mL}$ ethyl acetate (EtOAc) extract and OVCAR3 cell line treated with $160 \mu \mathrm{g} / \mathrm{mL}$ EtOAc extract of A. marina could be observed on western blot gel. C, control and T, treatment. The grouping of blots cropped from different gels. 
A.

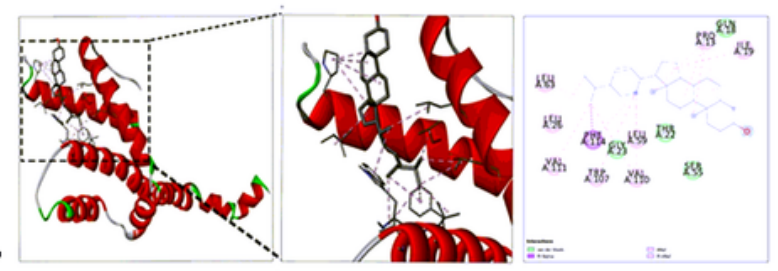

B.

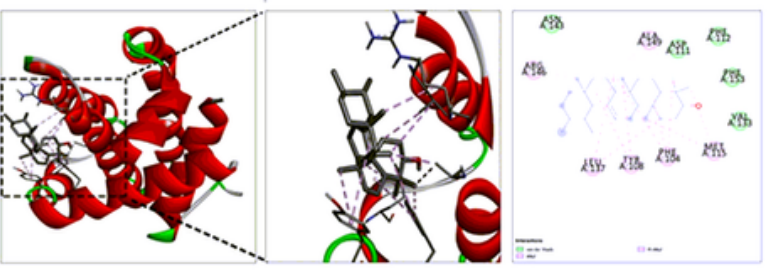

C.

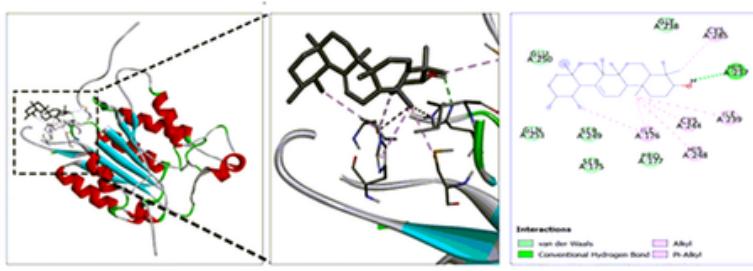

D.

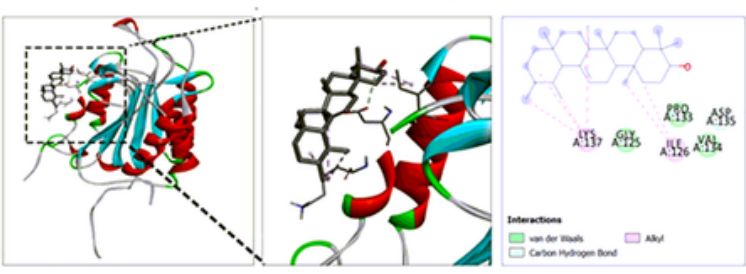

E.

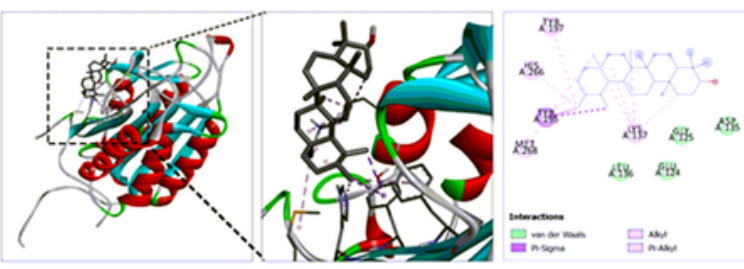

F.

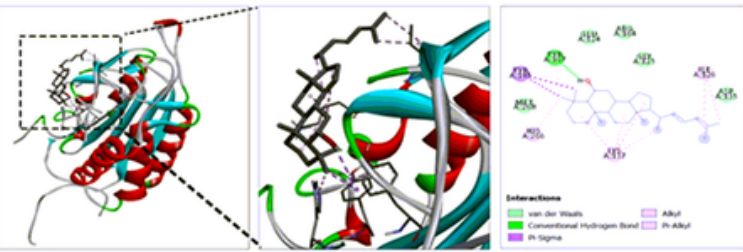

G.

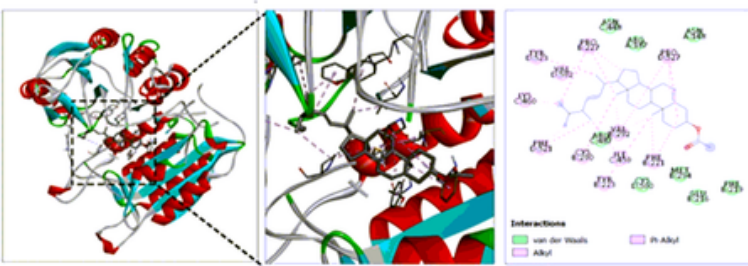

Figure 7

Computational modeling of interaction of bioactive compounds in ethanol and ethyl acetate extracts of Avicennia marina leaves on apoptosis peptides demonstrating by the three-dimensional plot of the binding sites and the two-dimensional plot of interactions. Interactions of A) BAX with stigmasterol, B) BCL-2 with beta amyrin, C) caspase- 1 with beta amyrin, D) caspase-3 with alpha amyrin, E) caspase 3 
with beta amyrin, F) caspase-3 with cholesta-22, 24-dien-5-ol,4,4-dimethyl, and G) caspase-7 with ergosta5,22-dien-3-ol, acetate.

\section{Avicennia marina leaves extract}

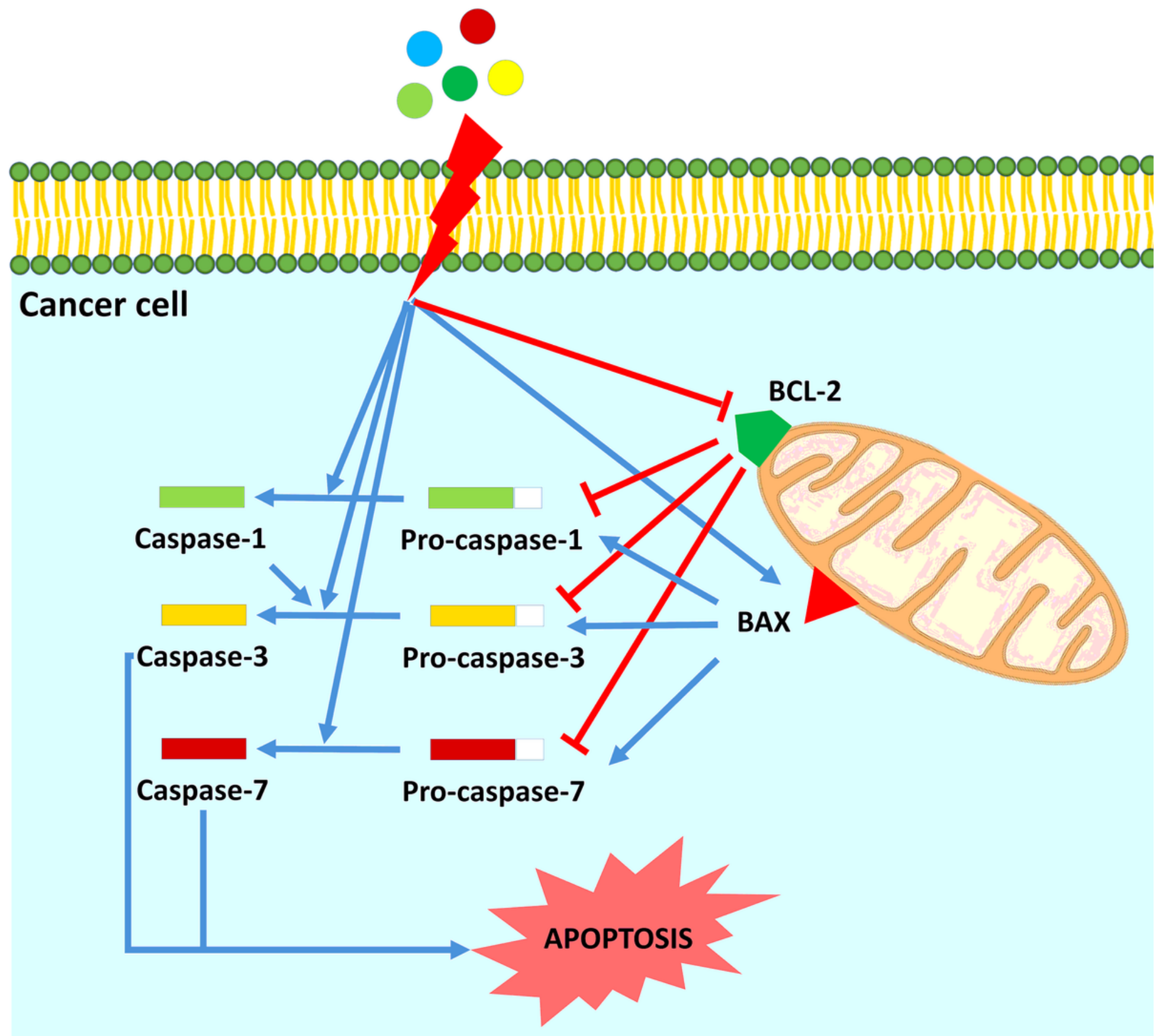

Figure 8

Avicennia marina leaves extract induces apoptosis pathway in HeLa, MCF-7 and OVCAR3 cell lines. Small colorful dots, red lighting, blue arrows and red hammer-head lines represent the A. marina extract five bioactive molecules were detected by docking technique, A. marina extract extract-induced stimulus, direct reactions and each inhibiting reaction, respectively. 


\section{Supplementary Files}

This is a list of supplementary files associated with this preprint. Click to download.

- Supplementaryfile.docx

- Supplementaryfile2westernblot.docx 